\title{
Physical characterization of Arabica ground coffee with different roasting degrees
}

\author{
EMINE NAKILCIOĞLU-TAŞ and SEMIH ÖTLEŞ \\ Department of Food Engineering, Faculty of Engineering, Ege University, 172, 35040 Izmir, Turkey \\ Manuscript received on February 26, 2018; accepted for publication on July 30, 2018
}

\begin{abstract}
How to cite: NAKILCIOĞLU-TAŞ E AND ÖTLEŞ S. 2019. Physical characterization of Arabica ground coffee with different roasting degrees. An Acad Bras Cienc 91: e20180191. DOI 10.1590/0001-3765201920180191.

Abstract: Roasting is a determinative operation on the final quality of coffee. Roasting process causes physical, chemical and sensory changes on coffee. In this study roasting degree effect on physical properties of Arabica fine ground coffee was examined. The bulk properties, particle property, reconstitution properties, moisture content, water activities and color properties were investigated in different roasting degrees of coffee. The results showed that the physical characteristics of coffee samples were influenced by the degree of roast. To have longer shelf life, lower cost and better physical attributes of Arabica fine ground coffee, the roasting process should be kept at a lower degree. At the same time the requests and expectations of customer should also be considered.
\end{abstract}

Key words: Arabica coffee, bulk density, flowability, roasting degree, water content.

\section{INTRODUCTION}

Coffee has been the most traded food product for decades. It is consumed frequently in the world. The first coffee house was opened in Meca at the end of the $15^{\text {th }}$ century and since that time coffee consumption has increased considerably all around the world (Farah 2009). Coffee production is earned over US\$ 90,000 million each year and it is produced in about 80 countries. In this case, it makes one of the economic basis of many tropical developing countries (Ramalho et al. 2013, Ribeiro et al. 2014). The Coffea arabica (Arabica) and Coffea canephora (Robusta) species are consumed mostly around the world (Esquivel and Jiménez 2012). Coffea arabica even corresponds to 70 $80 \%$ of world coffee production (Kroschwitz and Seidel 2004).

Correspondence to: Emine Nakilcioğlu-Taş

E-mail: emine.nakilcioglu@ege.edu.tr

ORCid: https://orcid.org/0000-0003-4334-2900
The ground coffee can be available at the market in different degree of roast which varied from very light to very dark color, according to the national preferences. In some parts of Europe, for example, dark roasted coffee is preferred while light medium to medium roasts are preferred in the United Kingdom and the United States (Clarke 2003, Farah 2009). In Turkey, medium roasts are traditional. During roasting process, raw coffee beans are exposed to high temperatures (about 200$240{ }^{\circ} \mathrm{C}$ ) for different times is ranging from 12 to 20 minutes in order to the desired properties of final products (Lerici and Nicoli 1990, Pittia et al. 2001, Jokanovic et al. 2012). While light roasting process produces sour, grassy, and underdeveloped flavor, medium roasting process tends to form a balanced taste and similar aroma to citrus flavor. In contrast, dark roasting process makes coffee low acidic (Lyman et al. 2003, Wang 2012). Furthermore, the complex chemical reactions and changes 
are caused during roasting, such as dehydration, non-enzymatic browning and pyrolysis (Dentan 1977, Dentan and Illy 1985, Massini et al. 1990, Gutiérrez et al. 1993, Wilson 1997, Frisullo et al. 2012). Roasting process is caused physical changes besides chemical, structural and sensorial changes (Sievetz and Desrosier 1979, Pittia et al. 2001). Considering the possible reasons of the relevant change of the physical properties during roasting, some of these effects could be explained as the noticeable reduction of density owing to the volume increase and the corresponding increase of brightness of coffee color determined by the increase of thermal process time (Massini et al. 1990, Gutiérrez et al. 1993, Pittia et al. 2001). Also, the decreased moisture content and water activity of roasted coffee can cause to change many physical properties of coffee with roasting process.

Although coffee consumption takes place during the year, coffee production is seasonal. For these reason, long term storage of coffee is necessary. Only in this way can be better prices achieved. The function of storage is to protect the commercial value of coffee as long as possible by maintaining the coffee unity with all of its characteristics (Ismail et al. 2013). In this context, the determination of physical properties of grounded coffee is also important in due to affecting powder behavior during handling and cooking operations as well as storage (Shrestha et al. 2007, OstrowskaLigeza and Lenart 2015).

When previous studies are examined, it is observed that the physical properties of many biological materials have been determined. The cashew nuts (Balasubramanian 2001, Oloso and Clarke 1993), pumpkin seeds (Joshi et al. 1993), soybean (Deshpande et al. 1993), lentil seeds (Çarman 1996), sunflower seeds (Gupta and Das 1997), white lupin (Ogut 1998), shea kernel (Olajide et al. 2000), apricot pit and its kernel (Gezer et al. 2002), terebinth fruits (Aydin and Özcan 2002), pigeon pea (Baryeh and Mangope 2003) and pistachio nut and its kernel (Kashaninejad et al. 2003, 2006) could be given as examples of these biological materials. Physical properties of coffee beans (roasted or raw) have been examined by other researchers (Corrêa et al. 2010, Mendonça et al. 2009, Frisullo et al. 2012, Pittia et al. 2001, 2007, Schenker et al. 2000, Jokanovic et al. 2012). Four studies have been found about the physical properties of coffee powder. One of them are related to the physical characteristics of instant coffee, and the other three are related to ground coffee's physical properties (Ishwarya and Anandharamakrishnan 2015, Nagaraju et al. 2016, Wang and Lim 2014, Pimenta et al. 2009). In literature, there are only two studies about some physical properties of ground coffees that had different roasting degrees were determined. The density, moisture content and color parameters of ground coffee that had different roasting degrees were determined in these studies (Wang and Lim 2014, Pimenta et al. 2009). However, other physical properties have not been investigated, yet. That is why; in this study almost all their physical properties have been studied.

The objective of present study is to evaluate the different physical characteristics such as bulk properties (bulk and tapped density, flowability, cohesiveness, porosity, caking degree and hygroscopicity), particle property (particle density), reconstitution properties (solubility, wettability and dispersibility), moisture content, water activities and color properties of ground Arabica coffees at different roasting degree: from green to very dark one. It is also aimed to demonstrate how the physical properties are affected by the roasting process. To the best of our knowledge, this is the first report to widely describe the physical characteristics of Arabica ground coffees with different roasting degrees which can be used in the preparation of Turkish-style coffee brew. 


\section{MATERIALS AND METHODS}

\section{MATERIALS}

\section{Samples}

Four different types of coffee samples (raw, light roasted, medium roasted and dark roasted coffee) produced from the same coffee beans were purchased from a local coffee shop (İlyas Gönen Coffee, Turkey). All of the analyses were performed with raw and roasted Arabica coffee beans having three different roasting levels. Roasting was performed at $200{ }^{\circ} \mathrm{C}$ and different roasting times using a tabletop drum roaster (Has Garanti HGS 1, Turkey). The heat transfer mechanism including convection, conduction and negligible level radiation during drum roasting ensured to obtain the appropriate flavor and aroma from the raw beans of $1000 \mathrm{~g}$ per drum. The roasting degrees were determined according to their $\mathrm{L}^{*}$ - values. Then, the coffee beans were ground to very finely $(<300 \mu \mathrm{m})$ with a Turkish coffee grinder. They were known as a coffee variety prepared by the method of Turkish style boiling.

\section{METHODS}

\section{Moisture Content}

Moisture contents of coffee samples were determined gravimetrically by oven at $105^{\circ} \mathrm{C}$ and expressed as percentage by mass (ISO 6673:2003 2013).

\section{Water Activity}

The water activity $\left(\mathrm{a}_{\mathrm{w}}\right)$ of coffee samples was measured by using a water activity measurement device (Testo 400, Lenzkirch, Germany) with 0.001 sensitivity.

\section{Color Analysis}

The Hunter $L^{*}, a^{*}, b^{*}$ values of coffee samples were measured with a chromameter (Hunter CFLX
45-2 Model Colorimeter, Hunter Lab, Reston, VA). The chroma $\left(\mathrm{C}^{*}\right)$, hue angle $\left(\mathrm{h}^{\circ}\right)$ and total color difference $\left(\Delta \mathrm{E}^{*}\right)$ values of coffee samples were calculated by using these CIELAB scale parameters and following the equations (Eqs. 1, 2 and 3):

$$
\begin{array}{llr}
\mathrm{C}^{*}=\sqrt{\left(\left(a^{*}\right)^{2}+\left(b^{*}\right)^{2}\right)} & \text { Eq. } 1 \\
\mathrm{~h}^{\mathrm{o}}=\tan ^{-1}\left(\frac{b^{*}}{a^{*}}\right) & \text { Eq. } 2 \\
\Delta \mathrm{E}^{*}=\sqrt{\left(\left(\Delta L^{*}\right)^{2}+\left(\Delta a^{*}\right)^{2}+\left(\Delta b^{*}\right)^{2}\right)} & \Delta L^{*}=L_{0} *-L^{*} & \text { Eq. } 3 \\
\Delta a^{*} & =a_{0} *-a^{*} \\
\Delta b^{*} & =b_{0} *-b^{*} &
\end{array}
$$

where $\mathrm{L}_{0}{ }^{*}, \mathrm{a}_{0}{ }^{*}, \mathrm{~b}_{0} *$ were values of raw coffee; the values of light/medium/dark roasted coffee were $L^{*}, a^{*}, b^{*}$.

\section{Particle Density}

The particle densities $\left(\rho_{\text {particle }}\right)$ of coffee samples were calculated by using the pycnometer method. $2.5 \mathrm{~g}$ of sample was placed in an empty liquid pycnometer having the volume of $25 \mathrm{~mL}$. It was filled by toluene and measured the volume. The $\rho_{\text {particle }}$ value was determined as the total particle weight divided by its total volume $\left(\mathrm{g} / \mathrm{cm}^{3}\right)$ (Krokida and Maroulis 2001, Fernandes et al. 2013).

\section{Bulk and Tapped Density}

The bulk density $\left(\rho_{\text {bulk }}\right)$ of coffee samples was determined by measuring the weight of the sample in the volume of $10 \mathrm{~mL}$, while the tapped density $\left(\rho_{\text {tapped }}\right)$ was quantified by measuring the volume of the sample in the weight of $3.0 \mathrm{~g}$ (Littringer et al. 2013). For $\rho_{\text {tapped }}$, the used cylinder was tapped firmly and continuously on the surface until the volume was no change. They were expressed as $g$ of coffee sample per $\mathrm{cm}^{3}$.

\section{Bulk Porosity}

The bulk porosity $(\mathcal{E})$ of coffee samples was calculated by using the values of $\rho_{\text {bulk }}$ and $\rho_{\text {particle }}$ as 
follows (Eq. (4)) and was expressed as percentage (Adekunle et al. 2013).

$\varepsilon=\left(\frac{\rho_{\text {particle }}-\rho_{\text {bulk }}}{\rho_{\text {particle }}}\right) \times 100$

Eq. 4

\section{Cohesiveness and Flowability}

Cohesiveness and flowability of coffee samples were evaluated with Hausner ratio (HR) (Hausner 1967) and Carr index (CI) (Carr 1965), respectively. CI and HR were calculated from the $\rho_{\text {bulk }}$ and $\rho_{\text {tapped }}$ values of sample as given below "Eqs. (5) and (6)":

$H R=\left(\frac{\rho_{\text {tapped }}}{\rho_{\text {bulk }}}\right)$

$C I=\left(\frac{\rho_{\text {tapped }}-\rho_{\text {bulk }}}{\rho_{\text {tapped }}}\right) \times 100$

The values of the Carr index and Hausner ratio based on the flow property that defines the quality of the coffee samples are presented in Table I. While the range is from excellent to passable is acceptable, others express to be lower quality of the powder (Shishir et al. 2014).

\section{Hygroscopicity and Caking Degree}

Approximately $1 \mathrm{~g}$ of sample put into a container with saturated $\mathrm{NaCl}$ solution $(75.29 \% \mathrm{RH})$ at 25 ${ }^{\circ} \mathrm{C}$ for the determining the higroscopicity of coffee samples. The samples were weighed after one week, and hygroscopicity of them was express as $\mathrm{g}$ of adsorbed moisture per $100 \mathrm{~g}$ solid (g/100 g) (Cai and Corke 2000, Fernandes et al. 2013).

After the determination of hygroscopicity, same samples were dried in an oven at $102{ }^{\circ} \mathrm{C}$ and then cooled. The dried samples were weighted and screened from a sieve of $500-\mu \mathrm{m}$ size. At the same time, the sieve was continuously shaken for $5 \mathrm{~min}$ with a shaking apparatus. The weight of sample left on the sieve was measured. The caking degree (CD) of coffee samples was calculated from "Eq. 7" (Jaya and Das 2004):
$C D(\%)=\left(\frac{100 \times a}{b}\right)$

Eq. 7

where $b$ was amount of the sieving coffee sample (g) and a was amount of the coffee sample remains on the sieve after sieving (g).

\section{Solubility}

$1 \mathrm{~g}$ of coffee sample was added $100 \mathrm{~mL}$ distilled water and they were agitated in a magnetic stirrer at $700 \mathrm{rpm}$ during $5 \mathrm{~min}$. The mixture was centrifuged for $5 \mathrm{~min}$ at $3000 \mathrm{~g}$ centrifugal force. One aliquot $(25 \mathrm{~mL})$ of the supernatant was transferred to a petri dish and dried in oven for $5 \mathrm{~h}$ at $103{ }^{\circ} \mathrm{C}$. After drying, the solubility percentage ( $\mathrm{g}$ of coffee sample per $100 \mathrm{~g}$ of water) was calculated by the difference of weights (Cano-Chauca et al. 2005, Sarabandi et al. 2014).

\section{Wettability}

The coffee samples $(0.1 \mathrm{~g})$ were sprinkled over the surface of $100 \mathrm{~mL}$ distilled water at $20{ }^{\circ} \mathrm{C}$ without agitation. The passed time until the last coffee particles sink was recorded and the wettability values of coffee samples were expressed as second (Fuchs et al. 2006, Fernandes et al. 2013).

\section{Dispersibility}

$10 \mathrm{~mL}$ of distilled water whose temperature is $25 \pm$ $1{ }^{\circ} \mathrm{C}$ was poured into a $50 \mathrm{ml}$ beaker. $1 \mathrm{~g}$ of coffee sample was added into the beaker. The sample was stirred strongly with a spoon for 15 s making 25 complete movements back and forth across the all diameter of the beaker. After the reconstituted sample was poured through a sieve of $212 \mu \mathrm{m}$ size, $1 \mathrm{~mL}$ of the sieved sample was transferred to a petri dish. It was oven-dried at $105{ }^{\circ} \mathrm{C}$ during $4 \mathrm{~h}$. The dispersibility of coffee samples was calculated according to the following equation "Eq. (8)": 
TABLE I

Characterization for Carr index and Hausner ratio (Shishir et al. 2014).

\begin{tabular}{ccc}
\hline Flowability & Carr Index (CI) & Hausner Ratio (HR) \\
\hline Excellent & $0-10$ & $1.00-1.11$ \\
Good & $0-15$ & $1.12-1.18$ \\
Fair & $16-20$ & $1.19-1.25$ \\
Passable & $21-25$ & $1.26-1.34$ \\
Poor & $26-31$ & $1.35-1.45$ \\
Very poor & $32-37$ & $1.46-1.59$ \\
Very, very poor & $>38$ & $>1.60$ \\
\hline
\end{tabular}

$\%$ Dispersibility $=\frac{(10+a) \times \% T S}{a \times\left(\frac{100-b}{100}\right)}$ Eq. 8

where a was the amount of coffee sample ( $\mathrm{g})$, b was moisture content of coffee sample and \% TS was also dry matter in percentage of the reconstituted sample had been passed through the sieve (Jinapong et al. 2008).

\section{Statistical Analysis}

All of the measurements were performed in triplicates and results are expressed as mean \pm standard deviation. The obtained data in this study were statistically analyzed by analysis of variance using the software SPSS version 20.0 software package (SPSS Inc., Chicago, IL) and significant difference among the different roasted ground Arabica coffee samples were determined using Duncan's multiple range tests at $p<0.05$. Also, the relationship between analyzed properties was assessed by Pearson's correlation coefficient.

\section{RESULTS AND DISCUSSION}

Moisture content and water activity of Arabica ground coffee samples were given in Tables II and III. Differences in roasted degree of coffee samples had significant effects $(p<0.05)$ on moisture content and water activity. Moisture content and water activity of coffee samples varied in the range of $2.36 \pm 0.025-7.99 \pm 0.003 \%$ (wet basis) and
$0.537 \pm 0.001-0.149 \pm 0.001$, respectively. While the obtained results related with moisture content in this study were shown a similar decrease at increasing roast level with those reported by Pittia et al. (2007), Pimenta et al. (2009), Wang (2012) and Wang and Lim (2014), the $a_{w}$ values were exhibited a similar change by the report of Pittia et al. (2007). The moisture content of raw coffee is approximately $7.95 \%$ and the moisture content of roasted coffee ranges from $1 \%$ to $5 \%$ depending on the species of coffee beans, roast level, roasting time-temperature conditions, and used cooling methods (Pittia et al. 2007, Wang and Lim 2015, Illy and Viani 2005). With the roasting process, the decreasing of the moisture content and water activity in coffee samples is a case which expected and desired. Moisture content plays a critical role about the handling of coffee (Barbosa-Canovas et al. 2005, Ishwarya and Anandharamakrishnan 2015). The low moisture content is very important to extend the shelf life and keeping acceptable consumption quality of these products (Shittu and Lawal 2007). The determined values of $a_{w}$ for the coffee samples are found to be below the minimal $\mathrm{a}_{\mathrm{w}}$ needed for the growth of spoilage organisms as the molds $(0.80)$, yeasts $(0.88)$ and bacteria $(0.91)$ (Ishwarya and Anandharamakrishnan 2015).

Color is an indicator which shows quality and consumer preferences of coffee product. While some consumers can prefer light-colored coffee, others could prefer a darker one (Ishwarya and Anandharamakrishnan 2015). The color parameters of coffee samples were shown in Figure 1 and also Table III. The Arabica raw coffee was used as a control sample for determining the total color difference of coffee samples and showed $\mathrm{L}^{*}, \mathrm{a}^{*}$, $b^{*}, C^{*}$ and $h\left(^{\circ}\right)$ values of $65.35 \pm 0.058,2.82 \pm$ $0.050,18.88 \pm 0.037,19.08 \pm 0.044$ and $1.42 \pm$ 0.002 , respectively.

It was determined that the total color difference among coffee samples increased, as the roasting degree of coffee increased in accordance with the 
TABLE II

Physical properties of Arabica ground coffee samples at different roast degrees*.

\begin{tabular}{|c|c|c|c|c|c|c|}
\hline Samples & $\begin{array}{l}\text { Bulk density } \\
\qquad\left(\mathrm{g} / \mathrm{cm}^{3}\right)\end{array}$ & $\begin{array}{c}\text { Tapped } \\
\text { density }(\mathrm{g} / \\
\left.\mathrm{cm}^{3}\right)\end{array}$ & $\begin{array}{c}\text { Particle } \\
\text { density }(\mathrm{g} / \\
\left.\mathrm{cm}^{3}\right)\end{array}$ & $\begin{array}{l}\text { Flowability } \\
\text { (CI) }\end{array}$ & Porosity (\%) & $\begin{array}{c}\text { Moisture } \\
\text { content }(\%)\end{array}$ \\
\hline Raw Coffee & $0.43 \pm 0.015 \mathrm{a}$ & $0.52 \pm 0.019 \mathrm{a}$ & $0.92 \pm 0.009 \mathrm{a}$ & $\begin{array}{c}21.66 \pm 0.47 \mathrm{a} \\
\text { (weak) }\end{array}$ & $52.91 \pm 0.26 \mathrm{c}$ & $7.99 \pm 0.003 \mathrm{a}$ \\
\hline $\begin{array}{l}\text { Light Roasted } \\
\text { Coffee }\end{array}$ & $0.39 \pm 0.011 b$ & $0.51 \pm 0.002 \mathrm{a}$ & $0.91 \pm 0.000 \mathrm{a}$ & $\begin{array}{l}12.28 \pm 0.01 \mathrm{c} \\
\text { (weak) }\end{array}$ & $57.41 \pm 0.49 \mathrm{c}$ & $4.99 \pm 0.021 b$ \\
\hline $\begin{array}{l}\text { Middle Roasted } \\
\text { Coffee }\end{array}$ & $0.33 \pm 0.009 \mathrm{c}$ & $0.41 \pm 0.010 \mathrm{~b}$ & $0.91 \pm 0.006 \mathrm{a}$ & $\begin{array}{l}19.03 \pm 0.18 \mathrm{~b} \\
\text { (weak) }\end{array}$ & $63.60 \pm 1.19 \mathrm{~b}$ & $2.52 \pm 0.050 \mathrm{c}$ \\
\hline $\begin{array}{l}\text { Dark Roasted } \\
\text { Coffee }\end{array}$ & $0.28 \pm 0.012 \mathrm{~d}$ & $0.34 \pm 0.007 \mathrm{c}$ & $0.91 \pm 0.008 \mathrm{a}$ & $\begin{array}{l}18.48 \pm 1.63 \mathrm{~b} \\
\text { (weak) }\end{array}$ & $69.06 \pm 1.55 \mathrm{a}$ & $2.36 \pm 0.025 \mathrm{~d}$ \\
\hline Samples & Wettability (s) & $\begin{array}{c}\text { Dispersibility } \\
(\%)\end{array}$ & $\begin{array}{c}\text { Solubility } \\
(\%)\end{array}$ & $\begin{array}{c}\text { Caking } \\
\text { Degree (\%) }\end{array}$ & $\begin{array}{c}\text { Hygroscopicity } \\
\text { (\%) }\end{array}$ & $\begin{array}{c}\text { Cohesiveness } \\
\text { (HR) }\end{array}$ \\
\hline Raw Coffee & $15 \pm 0.14 \mathrm{c}$ & $11.42 \pm 0.05 \mathrm{a}$ & $3.11 \pm 0.01 \mathrm{~b}$ & $14.42 \pm 3.42 \mathrm{~d}$ & $6.44 \pm 0.04 c$ & $\begin{array}{c}1.28 \pm 0.008 \mathrm{a} \\
(\text { medium })\end{array}$ \\
\hline $\begin{array}{l}\text { Light Roasted } \\
\text { Coffee }\end{array}$ & $22 \pm 0.74 \mathrm{c}$ & $\begin{array}{c}11.00 \pm 0.09 \\
\mathrm{a}, \mathrm{b}\end{array}$ & $3.14 \pm 0.00 \mathrm{~b}$ & $33.02 \pm 4.00 \mathrm{c}$ & $8.64 \pm 0.60 b$ & $\begin{array}{l}1.14 \pm 0.000 \mathrm{c} \\
(\text { medium })\end{array}$ \\
\hline $\begin{array}{l}\text { Middle Roasted } \\
\text { Coffee }\end{array}$ & $39 \pm 6.81 \mathrm{~b}$ & $10.25 \pm 0.57 \mathrm{~b}$ & $3.46 \pm 0.05 \mathrm{a}$ & $66.50 \pm 1.23 b$ & $8.83 \pm 0.30 b$ & $\begin{array}{l}1.24 \pm 0.003 \mathrm{~b} \\
\quad(\text { medium })\end{array}$ \\
\hline $\begin{array}{l}\text { Dark Roasted } \\
\text { Coffee }\end{array}$ & $204 \pm 5.52 \mathrm{a}$ & $10.18 \pm 0.26 b$ & $3.48 \pm 0.13 \mathrm{a}$ & $84.62 \pm 8.16 \mathrm{a}$ & $10.52 \pm 0.10 \mathrm{a}$ & $\begin{array}{l}1.23 \pm 0.024 \mathrm{~b} \\
\quad(\text { medium })\end{array}$ \\
\hline
\end{tabular}

Results are given as mean \pm standard deviation.

*The values designated by the different letters $(\mathrm{a}, \mathrm{b}, \mathrm{c}, \mathrm{d})$ in the column of the table are significantly different $(p<0.05)$.

results of Mendonça et al. (2009) and statistically significant difference was found as well. Also, the difference was found statistically important among the other color parameters of coffee samples that had different roasting degrees $(p<0.05)$. Arabica light roasted coffee had the highest $a^{*}, b^{*}, C^{*}$ values and the highest $\mathrm{L}^{*}$ and $\mathrm{h}^{\circ}$ values belonged to Arabica raw coffee statistically $(p<0.05)$. The lowest color parameters, except the $h^{\circ}$ value, were found in Arabica dark roasted coffee $(p<0.05)$. Generally, all color parameters, except $\Delta \mathrm{E}$, decreased with increasing the degree of roast. In coffee, the characteristic color, aroma and flavor development are occurred during roasting (Jokanovic et al. 2012). Coffee color is changed owing to the nonenzymatic browning and pyrolysis reactions (Pittia et al. 2001). Yellow-green color of raw coffee turns to a brown-black roasted color. Browning is characterized by a decrease of $L^{*}, a^{*}$ and $b^{*}$ as well as of $\mathrm{h}\left({ }^{\circ}\right.$ ) values (Jokanovic et al. 2012, Pittia et al.
2001). At the same time, it is expected that the value of $\mathrm{C}^{*}$ decreases with increasing of roasting degree as it is in this study. The observations obtained in this study were found to be similar with the results of Pittia et al. 2001, 2007, Jokanović et al. 2012, Wang 2012 and Nagaraju et al. 2016.

Since the density indicates how much material by weight in a given volume, the determination of coffee density is very important for processing, packaging, storage and transport (Cai and Corke 2000, Santana et al. 2014, Barbosa-Canovas and Juliano 2005). The density values (particle density, bulk density and tapped density) of coffee samples were tabulated in Table II. While the coffee samples showed significant changes both in bulk density and in tapped density, no statistically significant difference was found between the particle densities of coffee samples $(p<0.05)$. The particle densities of coffee samples were approximately 0.91-0.92 $\mathrm{g} / \mathrm{cm}^{3}$. The range of bulk density was from 0.28 
TABLE III

$C^{*}, \mathbf{h}\left(^{\circ}\right)$ and $\Delta \mathrm{E}$ color properties and water activities of Arabica ground coffee samples at different roast degrees*.

\begin{tabular}{lcccc}
\hline \multicolumn{1}{c}{ Samples } & $\mathbf{C}^{*}$ & $\left.\mathbf{h} \boldsymbol{(}^{\circ}\right)$ & $\Delta \mathbf{E}$ & Water activity \\
\hline Raw Coffee & $19.08 \pm 0.044 \mathrm{c}$ & $1.42 \pm 0.002 \mathrm{a}$ & - & $0.537 \pm 0.001 \mathrm{a}$ \\
Light Roasted Coffee & $31.42 \pm 0.11 \mathrm{a}$ & $1.04 \pm 0.00 \mathrm{~b}$ & $32.01 \pm 0.11 \mathrm{c}$ & $0.499 \pm 0.004 \mathrm{~b}$ \\
Middle Roasted Coffee & $24.61 \pm 0.20 \mathrm{~b}$ & $0.93 \pm 0.00 \mathrm{c}$ & $38.72 \pm 0.12 \mathrm{~b}$ & $0.278 \pm 0.003 \mathrm{c}$ \\
Dark Roasted Coffee & $6.27 \pm 0.19 \mathrm{~d}$ & $0.65 \pm 0.01 \mathrm{~d}$ & $51.72 \pm 0.11 \mathrm{a}$ & $0.149 \pm 0.001 \mathrm{~d}$ \\
\hline
\end{tabular}

Results are given as mean \pm standard deviation.

*The values designated by the different letters (a,b,c,d) in the column of the table are significantly different $(p<0.05)$.

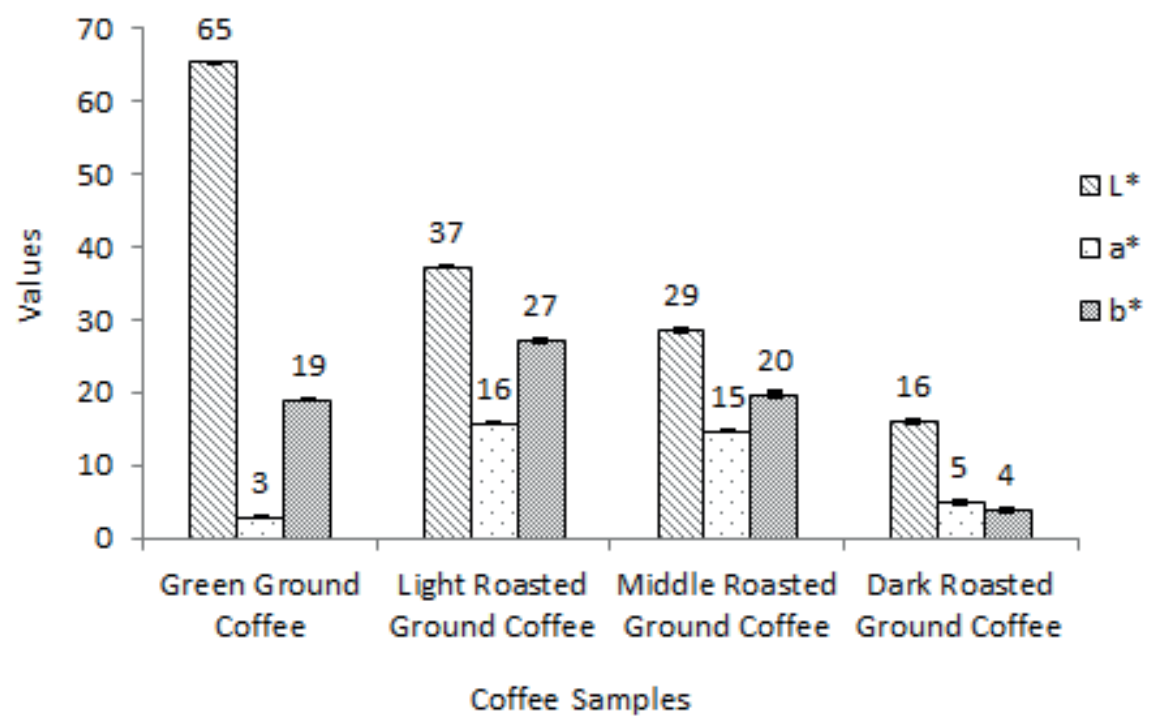

Figure 1 - L*, a* and $b^{*}$ values for Arabica ground coffee samples at different roast degrees.

$\pm 0.012 \mathrm{~g} / \mathrm{cm}^{3}$ (dark roasted coffee) and $0.43 \pm$ $0.015 \mathrm{~g} / \mathrm{cm}^{3}$ (raw coffee). The tapped density also range spread from $0.34 \pm 0.007 \mathrm{~g} / \mathrm{cm}^{3}$ (dark roasted coffee) to $0.52 \pm 0.019 \mathrm{~g} / \mathrm{cm}^{3}$ (raw coffee). There were not significant differences between the tapped densities of raw coffee and light roasted coffee $(p<0.05)$. During roasting, the noticeable reduction of density is observed owing to the volume increase and weight decrease of the bean determined by the increase of the pressure internal gases and products of the heat-induced reactions such as water vapor, carbon dioxide and pyrolysis reaction products (Massini et al. 1990, Gutiérrez et al. 1993, Pittia et al. 2001). It is thought that coffee density was decreased due to its increase in volume and simultaneous weight loss with increasing roasting degree. Also, low bulk density of a coffee product is not appealing, resulting in a larger volume packaging. The coffee contacts a greater amount of air and then, it can be oxidized (Barbosa-Canovas and Juliano 2005, Cai and Corke 2000, Santana et al. 2014). The lower tapped and bulk densities of dark roasted coffee when compared to other samples can be due to its lower residual moisture content and a little less cohesive than others in this study. While the raw coffee is preferred for the lower packaging and transit costs in long distance transportation, the dark roasted one can be preferred due to its lower oxidation risks. Similar observations to this study about particle density and/or bulk density and/ or tapped density change with the degree of roast in coffee beans were reported by others as well (Mendonça et al. 2009, Pittia et al. 2001). 
The porosity is a value calculated by dividing the volume of the voids in the coffee by total coffee volume. This property is related to the particle density and bulk density of coffee (Ortega-Rivas 2009). The effect of roasting degree on the bulk porosity of coffee samples was given in Table II. A statistically significant change was found among the porosity values of samples and the porosity development in coffee samples significantly increased with increasing the degree of roasting process in the range of $43.68 \pm 0.52-62.06 \pm$ $1.15 \%(p<0.05)$. In roasting process, since the simultaneous weight loss and volume increase, the density of coffee decreases and porous structure develops. This development is highly dependent on the roasting conditions (Ortola et al. 1998, Schenker et al. 2000). The differences between particle density and bulk density of coffee samples in this study were an indicator of coffee samples which had comparably high internal/external (or both) porosity. Roasting-induced changes which occur in pore structure have a significant effect on the final product quality in that the pore structure controls the mass transfer during storage (Radtke 1975, Saleeb 1975, Massini et al. 1990, Schenker et al. 2000). The loss of flavor compounds and the following change in flavor profile during storage are related to the pore structure of coffee (Holscher and Steinhart 1992, Gutiérrez et al. 1993, Schenker et al. 2000). That's why porosity in coffee is one of the major physical characteristics. The coffee's porosity is increased owing to both the degradation of the intercellular matrix and the destruction of the cells during roasting process. After roasting, the similar change in porosity of coffee samples has been also observed into the results of Dutra et al. (2001) and Frisullo et al. (2012).

Carr Index and Hausner Ratio values represent the flowability and cohesiveness properties of coffee samples, respectively. It is very important that coffee has appropriate flow properties for the manufacturer and consumer for handling, measuring, packaging, transportation, storage, bag filling and emptying, dosing purposed and selecting parameters in mixing and conditioning (Caliskan and Dirim 2016). Carr Index and Hausner Ratio values of coffee samples with different roasting degrees were presented in Table II. Findings pointed out that there was significant difference in the flowability and cohesiveness properties of all coffee samples, except middle and dark roasted coffees, at different roasting degrees $(p<0.05)$. Raw coffee sample exhibited the highest flowability and cohesiveness properties (21.66 \pm 0.47 and $1.28 \pm 0.008$ ) while the lowest flowability and cohesiveness properties was determined in light roasted coffee sample $(12.28 \pm 0.01$ and $1.14 \pm 0.000)$. According to Table I, all of the coffee samples had week flowability and medium cohesiveness properties. The increase in roasting degree of coffee samples did not have influence on the flow properties of coffee. Only, it caused to a decrease in flow characteristic of samples with roasting process. Koç et al. (2011) reported that the powders had small particle exhibited lower flow characteristics. In this study, coffee samples could have a low flow attributes due to they had fine particle size.

One of the important factor for powder reconstitution is an absorption of water owing to the fact that it can lead to caking reducing dispersibility (Fernandes et al. 2013). Hygroscopicity is known as capacity of absorb water from the surroundings. Coffee should be stored in dry places with low moisture content. Otherwise incidence of microorganisms that cause low final quality in product will increase. On the other hand, a decrease in moisture content is brought about economic losses because of mass loss (Yazdani et al. 2006, Corrêa et al. 2010). The values obtained for hygroscopicity (Table II) changed from $6.44 \pm 0.04$ (raw coffee) to $10.52 \pm 0.10 \%$ (dark roasted coffee), and they were significantly influenced by roasting degrees of coffee samples $(p<0.05)$. Fernandes et al. (2013) 
explained that higher hygroscopicity values were obtained when powder had lower moisture content due to higher water concentration gradient between powder and atmosphere. Similar behavior has been found in this study for coffee samples at different roasting degrees. The hygroscopicity of the coffee samples affected in an opposite manner to that of the moisture content, and a decrease in the degree of roast caused hygroscopicity reduction.

The powder caking is an undesired reaction which the powder turns into an agglomerated and sticky material at the initial and then the functionality of powder decreases, smoothness and quality loss occur. The presence of plasticizing water on the surface of particles is known as the main cause of agglomeration (Aguilera et al. 1995, Oliveira et al. 2014). In this study, the caking degree of coffee samples (Table II) significantly increased from $14.42 \pm 3.42$ to $84.62 \pm 8.16 \%$ with increasing roasting degree from non-roasted to dark roasted one $(p<0.05)$. Differences in roasted degree of coffee samples had significant effects $(p<0.05)$ on caking degree of them. Caking behavior of the powder is influenced by high temperature process, moisture addition and presence of liquid components (such as oil, organic acids) and highly hygroscopic component (such as sugars, polyols) in the product structure (Rahman 2007). In this study, it is considered that the content of moisture and oil in the structure affects the degree of caking. Also, the fine particles of coffee due to the increase in the particle surface area cause a higher affinity to moisture. As a result of this, the degree of cake in coffee samples increases (Kurozawa et al. 2009, Koç et al. 2011). The higher hygroscopicity of the particles and the finer the particles, the faster will be the caking (Rahman 2007). Studies about sucrose and grugru palm powder by Mathlouthi and Rogé (2003) and Oliveira et al. (2014) reported that caking degree changed linearly by hygroscopicity of products. The same can be seen in coffee samples with different roasting degrees which the powder had the highest caking with highest hygroscopicity. According to the methodology " 15 a" that described by Gea Niro Research Laboratory (2005), the classification of powder caking degree is non-caking powder $(<10 \%)$, slightly caking powder (10.1-20\%), very caking powder $(20.1-$ $50 \%)$ and extremely caking powder (50-100\%). In this study it was found that the raw coffee was slightly caking, light roasted coffee was very caking and middle and dark roasted coffee were extremely caking.

The powder particles are wetted and have sunk, they would instantly start to disperse uniformly as individual particles and then dissolve into the water (Fang et al. 2008). The dispersibility and wettability characteristics of the powder are a directly relationship with particle size, uniformity index, caking degree, hygroscopicity and some chemical factors such as sugar, fat and moisture content (Buffo et al. 2002, Sarabandi et al. 2014, Ortega-Rivas 2009, Jinapong et al. 2008, Fernandes et al. 2013, Shittu and Lawal 2007). The data including wettability and dispersibility values of coffee samples were presented in Table II. While the dispersibilty values of coffee samples varied from $10.18 \pm 0.26$ (dark roasted coffee) to $11.42 \pm$ $0.05 \%$ (raw coffee), the time needed for the coffee samples to become completely wet changed from $15 \pm 0.14$ (raw coffee) to $204 \pm 5.52 \mathrm{~s}$ (dark roasted coffee). Significant differences were generally detected between wettability and dispersibility properties of coffee samples had different degree of roast $(p<0.05)$. However, raw coffee and light roasted coffee samples and light roasted coffee, medium roasted coffee and dark roasted coffee samples had the same feature in terms of dispersibility properties $(p<0.05)$. The raw coffee and light roasted coffee samples also had the same feature in terms of wettability properties $(p<0.05)$. In this study, dispersibility decreased and wetting time increased with an increase in the caking degree and hygroscopicity. Also, the dispersibility 
and moisture content of coffee samples decreased simultaneously. Actually, an increase in roasting degree of coffee samples led to a decrease in their moisture content, which indirectly affected the dispersibility of samples. These results are parallel with the results and inferences obtained by Shittu and Lawal (2007) and Fernandes et al. (2013). It could be seen that the wettability markedly increased with decreasing dispersibility of coffee samples which is in similar with the postulations of Jinapong et al. (2008).

Many factors affect solubility such as processing conditions, storage conditions, powder composition, $\mathrm{pH}$, density, and particle size (Rahman 2007). Solubility index values of coffee samples that had different roasting degrees were ranged between $3.11 \pm 0.01$ (raw coffee) and $3.48 \pm 0.13$ $\%$ (dark roasted coffee) (Table II). The roasting degrees did not present significant effects $(p<0.05)$ on the solubility of the raw and light roasted coffees samples and of middle and dark roasted coffee samples. According to these results, coffee samples had low degree of solubility in water. This is an expected case. Because Arabica ground coffee that can be prepared by the method of Turkish style boiling and it is not an instant coffee. After cooking, it leaves residue on the bottom of the cup. Browning reactions occurs at roasting degrees in coffee samples decrease solubility (Rahman 2007). It is known that the powder with small particles exhibits low solubility and flowability (Toth and Pallai-Varsanyi 2006, Santana et al. 2014). Large particles may sink while small ones are dustier and float on the water. Small particles exhibit unequal wetting and reconstitution (Potter 1968, Goula and Adamopoulos 2008). Also the porosity is improved solubility (Koç et al. 2011, Rogers et al. 2008). Additionally, Papadakis et al. (1998) reported that the hygroscopicity and solubility of the powder increased with decreases of moisture content (Goula and Adamopoulos 2008). According to Goula and Adamopoulos (2008), the lower moisture content in the powder causes more soluble into the water and so time required for the powder to dissolve decreases. All the above studies are in agreement with the solubility results in this study.

This paper is the first study which the physical properties of the ground coffee are examined so deeply and the effects of roasting degree on the physical properties of ground coffee are determined. There is no study about the comparison of flowability, cohesiveness, hygroscopicity, caking degree, dispersibility, wettability and solubility of coffee and so, the data obtained related with these properties of coffee samples are not compared with previous studies in literature.

In the current study, to explore relations among physical properties of coffee samples that had different roasting degrees, a correlation matrix was calculated (Table IV). There was generally significant correlation between most of the measured physical properties of coffee samples, except particle density, flowability, cohesiveness that had statistically insignificant linear correlation among other analyses results of coffee samples. Only, the flowability and cohesiveness relationship indicated a high $(0.99)$ correlation $(p<0.01)$. Statistically significant correlations were observed between bulk density, tapped density, porosity and water activity of coffee samples with wettability of coffee samples at a 99\% significance level and statistically significant correlations were also determined between caking degree and hygroscopicity of coffee samples with wettability of coffee samples at $95 \%$ significance level. Among the other physical properties of coffee samples with wettability of them were obtained no statistically significant correlations. Other than these, no statistically significant correlations were calculated between $\mathrm{a}^{*}$ and $\mathrm{C}^{*}$ values of coffee samples with $\mathrm{L}^{*}$ and $\mathrm{h}\left({ }^{\circ}\right)$ values of coffee samples. Between the $\mathrm{b}^{*}$ and $\mathrm{h}\left({ }^{\circ}\right)$ values of coffee samples with $\Delta \mathrm{E}$ value of coffee samples were found as statistically insignificant linear correlation. It is quite surprising that there 


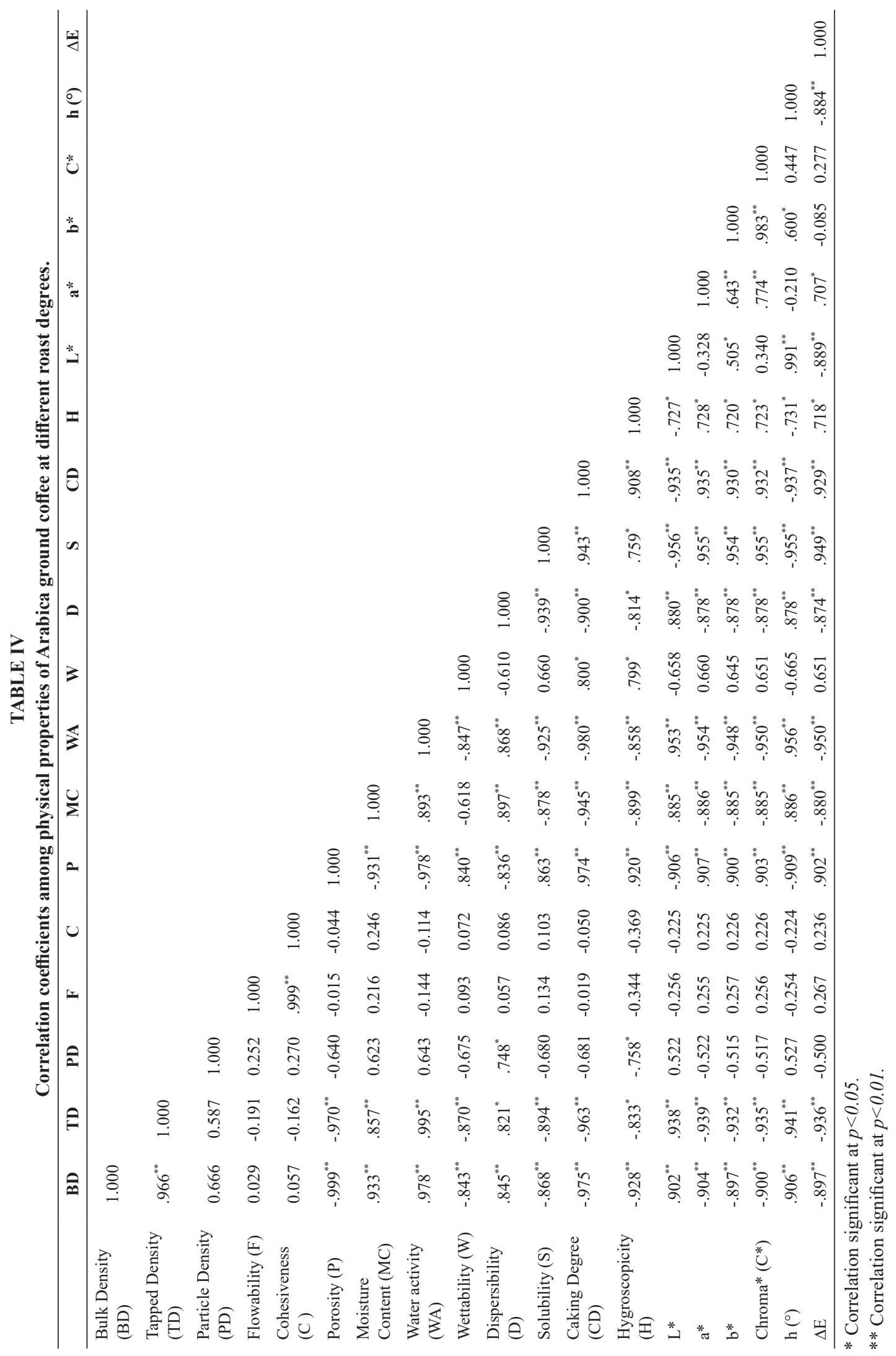


was no statistically significant correlation between wettability and moisture content of coffee samples. However, some studies advocating the opposite of this data is available in the literature (Buffo et al. 2002, Sarabandi et al. 2014). This study reveals that the wettability property is not related to the moisture content. While statistically significant positive correlations were observed between tapped density and particle density of coffee samples with dispersibility of coffee samples, statistically significant negative correlations were obtained between higroscopicity of coffee samples and dispersibility of coffee samples $(p<0.05)$. The correlations between $\mathrm{L}^{*}$ and $\mathrm{h}\left({ }^{\circ}\right)$ values of coffee samples with $b^{*}$ value were 0.50 and 0.60 , respectively and they seemed as poor $(p<0.05)$. Also, there was negative correlations between particle density, $\mathrm{L}^{*}$ and $\mathrm{h}\left({ }^{\circ}\right)$ values of coffee samples with higroscopicity of coffee samples, while positive correlations was found between all of color parameters (except $\mathrm{L}^{*}$ and $\mathrm{h}\left({ }^{\circ}\right)$ values) and solubility of coffee samples with higroscopicity of coffee samples $(p<0.05)$. It was determined that there were statistically significant and generally high correlations among the obtained results from all the physical analysis other than mentioned above performed in the coffee samples at $99 \%$ significance level.

These correlations confirmed the results obtained from the experimental data that the change of bulk density, tapped density, particle density, flowability, cohesiveness, porosity, solubility, caking degree, hygroscopicity, wettability, dispersibility, moisture content, water activity and color properties of ground Arabica coffees with changing roasting degree of coffee. Even if there were some exceptions, high correlations had been found among the physical characteristics of coffee samples.

This is the first study in which the physical properties of Arabica ground coffee are studied in such a detailed way and the effect of roasting degree on physical properties of coffee is examined in depth. Only, two studies have found about the changing of the density, moisture content and color parameters of ground coffee with different roasting degree in literature (Wang and Lim 2014, Pimenta et al. 2009). These studies were insufficient to explain how the degree of roast changes the physical properties of the coffee. The present study will fill the incomplete information about roasting degree effect on the physical properties of ground coffee in the literature.

\section{CONCLUSIONS}

Roasting is a process that causes to change many physical properties of coffee such as bulk density, tapped density, flowability and color as well as sensory and chemical properties. In this study, effects of roasting process on the almost all physical properties of Arabica ground coffee were investigated with respect to bulk, particle and reconstitution properties, moisture content, water activity and color for the first time in detail. In the literature a few studies have found related with the research on the density, moisture content and color parameters of ground coffee. It has been found that as the roasting degree of coffee increases, bulk, and tapped densities, moisture content, water activity of coffee decreases and their particle density and the properties of flowability and cohesiveness do not change. The caking degree, hygroscopicity and porosity characteristics of coffee increase with increasing the degree of roasting process. When the reconstitution properties are examined, it is found that the wetting time is longer. Also, the solubility of coffee increase after the degree of light roast and the dispersibility of coffee decrease with the first stage of roasting process. Arabica ground coffee which is a coffee prepared by the method of Turkish style boiling, is not belonged to a soluble coffee variety. Therefore, the reconstitution properties of analyzed coffee are not expected to be very good. 
It is determined that roasting process does not have a positive effect on reconstitution properties of coffee. According to roasting degree, the color of coffee changes from green to light brown, brown and dark brown. As expected, the changing of color increases. Consequently, dark roasted Arabica ground coffee has a higher capacity of moisture absorption and higher risk of oxidation, higher packaging cost due to packaging in higher volume, lower quality characteristics due to mass transfer of flavor components. As the roasting degree of coffee increases, the quality of the product decreases and both of production costs and microbial deterioration risk increase. Results reveal that Arabica ground coffee that roasted less has a longer shelf life and a lower cost and maintains the quality characteristics better.

\section{AUTHOR CONTRIBUTIONS}

E. NAKILCIOĞLU-TAŞ designed the study, performed the experiments and analysed the data. E. NAKILCIOĞLU-TAŞ and S. ÖTLEŞ discussed the results and commented on the manuscript. E. NAKILCIOĞLU-TAŞ wrote the article.

\section{REFERENCES}

ADEKUNLE AA ET AL. 2013. Physical and thermal properties of baobab fruit pulp powder. IJERA 3(3): 925928.

AGUILERA J, DEL VALLE J AND KAREL M. 1995. Caking phenomena in amorphous food powders. Trens Food Sci Technol 6(5): 149-155.

AYDIN C AND ÖZCAN M. 2002. Some physico-mechanic properties of terebinth (Pistacia terebinthus L.) fruits. J Food Eng 53(1): 97-101.

BALASUBRAMANIAN AD. 2001. Physical properties of raw cashew nut. J Agr Eng Res 78(3): 291-297.

BARBOSA-CANOVAS GV ET AL. 2005. Bulk properties. In: Ortega-Rivas E, Juliano P and Yan H (Eds), Food powders: physical properties, processing, and functionality. NewYork: Kluwer Academic/Plenum Publishers, New York, USA, p. 55-88.

BARBOSA-CANOVAS GV AND JULIANO P. 2005. Physical and chemical properties of food powders. In: Onwulata
C (Ed), Encapsulated and powdered foods. Boca Raton: Taylor \& Francis, USA, p. 39-71.

BARYEH EA AND MANGOPE BK. 2003. Some physical properties of QP-38 variety pigeon pea. J Food Eng 56(1): 59-65.

BUFFO RA ET AL. 2002. Effects of agglomeration on the properties of spray-dried encapsulated flavours. Flavour Fragr J 17(4): 292-299.

CAI YZ AND CORKE H. 2000. Production and properties of spray-dried amaranthus betacyanin pigments. J Food Sci 65(7): 1248-1252.

CALISKAN G AND DIRIM SN. 2016. The effect of different drying processes and the amounts of maltodextrin addition on the powder properties of sumac extract powders. Powder Technol 287: 308-314.

CANO-CHAUCA M ET AL. 2005. Effect of the carriers on the microstructure of mango powder obtained by spray drying and its functional characterization. Innov Food Sci Emerg Technol 6(4): 420-428.

CARR RL. 1965. Evaluating flow properties of solids. Chem Eng (72): 163-168.

ÇARMAN K. 1996. Some physical properties of lentil seeds. J Agr Eng Res 63(2): 87-92.

CLARKE RJ. 2003. Coffee: green coffee / roast and ground. In: Benjamin FTC and Finglas P (Eds), Encyclopedia of food sciences and nutrition. Volume 3, Oxford: Academic Press, UK.

CORREAA PC ET AL. 2010. Moisture sorption isotherms and isosteric heat of sorption of coffee in different processing levels. Int J Food Sci Technol 45(10): 2016-2022.

DENTAN E. 1977. Structure fine du grain de café vert. In: Proceedings of the $8^{\text {th }}$ Asic Colloquium, Paris. $8^{\text {th }}$ International Scientific Colloquium on Coffee, Paris, $\mathrm{p}$. 59-64.

DENTAN E AND ILLY A. 1985. Étude microscopique de grains de café matures, immatures et immatures fermentés Arabica Santos. In: Proceedings Of The $11^{\text {th }}$ Asic Colloquium, Paris. $11^{\text {st }}$ International Scientific Colloquium on Coffee, Paris, p. 341-368.

DESHPANDE SD, BAL S AND OJHA TP. 1993. Physical properties of soybean. J Agr Eng Res 56(2): 89-98.

DUTRA E, OLIVEIRA L, FRANCA A, FERRAZ V AND AFONSO RJC. 2001. A preliminary study on the feasibility of using the composition of coffee roasting exhaust gas for the determination of the degree of roast. J Food Eng 47(3): 241-246.

ESQUIVEL P AND JIMÉNEZ VM. 2012. Functional properties of coffee and coffee by-products. Food Res Int 46(2): 488-495.

FANG Y, SELOMULYA C AND CHEN XD. 2008. On measurement of food powder reconstitution properties. Dry Technol 26(1): 3-14. 
FARAH A. 2009. Coffee as a speciality and functional beverage. In: Paquin P (Ed), Functional and speciality beverage technology. UK: Woodhead Publishing Limited, p. 370-395.

FERNANDES RVB, BORGES SV AND BOTREL DA. 2013. Influence of spray drying operating conditions on microencapsulated rosemary essential oil properties. Ciencia Tecnol Alime 33(Suppl. 1): 171-178.

FRISULLO P ET AL. 2012. Coffea arabica beans microstructural changes induced by roasting: An X-ray microtomographic investigation. J Food Eng 108(1): 232237.

FUCHS M ET AL. 2006. Encapsulation of oil in powder using spray drying and fluidised bed agglomeration. J Food Eng 75(1): 27-35.

GEA NIRO RESEARCH LABORATORY. 2005. Degree of caking. Soeborg, Denmark.

GEZER I, HACISEFEROĞULLARI H AND DEMIR F. 2002. Some physical properties of Hacıhaliloğlu apricot pit and its kernel. J Food Eng 56: 49-57.

GOULA AM AND ADAMOPOULOS KG. 2008. Effect of maltodextrin addition during spray drying of tomato pulp in dehumidified air: I. drying kinetics and product recovery. Dry Technol 26(6): 714-725.

GUPTA RK AND DAS SK. 1997. Physical properties of sunflower seeds. J Agr Eng Res 66(1): 1-8.

GUTIÉRREZ C ET AL. 1993. Análisis por meb de la porosidad del café tostado. In: Proceedings Of The $15^{\text {th }}$ Asic Colloquium, Paris. $15^{\text {th }}$ International Scientific Colloquium on Coffee, Paris, p. 661- 671.

HAUSNER HH. 1967. Friction conditions in a mass of metal powder. Int J Powder Metall 3(4): 7-13.

HOLSCHER W AND STEINHART H. 1992. Aromaveränderungen beim Altern von Röstkaffee. Lebensmittelchemie (46): 106-111.

ILLY A AND VIANI R. 2005. Espresso coffee: the science of quality. $2^{\text {nd }}$ ed., San Diego: Elsevier Academic Press.

ISHWARYA SP AND ANANDHARAMAKRISHNAN C. 2015. Spray-freeze-drying approach for soluble coffee processing and its effect on quality characteristics. J Food Eng 149: 171-180.

ISMAIL I, ANUAR MS AND SHAMSUDIN R. 2013. Effect on the physico-chemical properties of liberica green coffee beans under ambient storage. Int Food Res J 20(1): 255264.

ISO 6673:2003. 2013. Green coffee - determination of loss in mass at 105 degrees C-ICS: 67.140.20. Available at: http:// www.iso.org/iso/catalogue_detail.htm?csnumber $=38375$ Accessed on December 10, 2016.

JAYA S AND DAS H. 2004. Effect of maltodextrin, glycerol monostearate and tricalcium phosphate on vacuum dried mango powder properties. J Food Eng 63(2): 125-134.
JINAPONG N, SUPHANTHARIKA M AND JAMNONG P. 2008. Production of instant soymilk powders by ultrafiltration, spray drying and fluidized bed agglomeration. J Food Eng 84(2): 194-205.

JOKANOVIC M ET AL. 2012. Changes of physical properties of coffee beans during roasting. Acta Period Technol 342(43): 21-31.

JOSHI DC, DAS SK AND MUKHERJEE RK. 1993. Physical properties of pumpkin seeds. J Agr Eng Res 54(3): 219229.

KASHANINEJAD M ET AL. 2003. Effect of drying methods on quality of pistachio nuts. Dry Technol 21(5): 821-838.

KASHANINEJAD M ET AL. 2006. Some physical properties of pistachio (Pistacia vera L.) nut and its kernel. J Food Eng 72(1): 30-38.

KOÇ M ET AL. 2011. Physicochemical characterization of whole egg powder microencapsulated by spray drying. Dry Technol 29(7): 780-788.

KROKIDA MK AND MAROULIS ZB. 2001. Structural properties of dehydrated products during rehydration. Int J Food Sci Technol 36(5): 529-538.

KROSCHWITZ JI AND SEIDEL A. 2004. Coffee. KirkOthmer encyclopedia of chemical technology, $1084 \mathrm{p}$.

KUROZAWA EL ET AL. 2009. Influence of spray drying conditions on physicochemical properties of chicken meat powder. Dry Technol 27: 1248-1257.

LERICI CR AND NICOLI MC. 1990. Il caffè: aspetti chimici, tecnologici e qualità della bevanda. Riv della Soc Ital di Sci degli Aliment 19: 1-16.

LITTRINGER EM ET AL. 2013. The morphology and various densities of spray dried mannitol. Powder Technol 246: 193-200.

LYMAN DJ ET AL. 2003. FTIR-ATR analysis of brewed coffee: effect of roasting conditions. J Agric Food Chem 51(11): 3268-3272.

MASSINI R ET AL. 1990. Study on physical and physicochemical changes of coffee beans during roasting. Note 1. Ital J Food Sci 2(2): 123-130.

MATHLOUTHI M AND ROGÉ B. 2003. Water vapour sorption isotherms and the caking of food powders. Food Chem 82(1): 61-71.

MENDONÇA JCF, FRANCA AS AND OLIVEIRA LS. 2009. Physical characterization of non-defective and defective Arabica and Robusta coffees before and after roasting. J Food Eng 92(4): 474-479.

NAGARAJU VD, RAMALAKSHMI K AND SRIDHAR BS. 2016. Cryo assisted spouted bed roasting of coffee beans. Innov Food Sci Emerg Technol 37: 138-144.

OGUT H. 1998. Some physical properties of white lupin. J Agric Food Chem 56: 273-277.

OLAJIDE JO, ADE-OMOWAYE BIO AND OTUNOLA ET. 2000. Some physical properties of shea kernel. J Agric Food Chem 76(4): 419-421. 
OLIVEIRA DM, CLEMENTE E AND DA COSTA JMC. 2014. Hygroscopic behavior and degree of caking of grugru palm (Acrocomia aculeata) powder. J Food Sci Technol 51(10): 2783-2789.

OLOSO AO AND CLARKE B. 1993. Some aspects of strength properties of cashew nuts. J Agr Eng Res 55(1): 27-43.

ORTEGA-RIVAS E. 2009. Bulk properties of food particulate materials: an appraisal of their characterisation and relevance in processing. Food Bioprocess Tech 2(1): 2844.

ORTOLA MD ET AL. 1998. Influence of roasting temperature on physicochemical properties of different coffees. Food Sci Technol Int 4(1): 59-66.

OSTROWSKA-LIGEZA E AND LENART A. 2015. Influence of water activity on the compressibility and mechanical properties of cocoa products. Food Sci Technol 60(2): 1054-1060.

PAPADAKIS SE, GARDELI C AND TZIA C. 1998. Raisin extract powder: Production, physical and sensory properties. In: Proceedings of the $11^{\text {st }}$ International Drying Symposium Ids '98, Halkidiki. $11^{\text {st }}$ International Drying Symposium IDS ‘98, Greece, p. 1207-1213.

PIMENTA TV ET AL. 2009. Roasting processing of cherry coffee: study of grain shape and temperature development influence on grain properties and sensorial snalysis. Bol Cent Pesqui Process Aliment 27: 97-106.

PITTIA P, DALLA ROSA M AND LERICI C. 2001. Textural changes of coffee beans as affected by roasting conditions. Lebensm Wiss Technol 175: 168-175.

PITTIA P, NICOLI MC AND SACCHETTI G. 2007. Effect of moisture and water activity on textual properties of raw and roasted coffee beans. J Texture Stud 38: 116-134.

POTTER NN. 1968. Food science. Westport: AVI Publishing Company.

RADTKE R. 1975. Das problem der $\mathrm{CO}_{2}$-desorption von röstkaffee unter dem gesichtspunkt einer neuen packstoffentwicklung. In: $7^{\text {th }}$ Asic Colloquium, Paris. $7^{\text {th }}$ International Scientific Colloquium on Coffee, Paris, $\mathrm{p}$. 323-333.

RAHMAN SM. 2007. Handbook of Food Preservation, $2^{\text {nd }}$ ed., Boca Raton, Florida: CRC Press, USA.

RAMALHO JC ET AL. 2013. Sustained photosynthetic performance of Coffea spp. under long-term enhanced $\left[\mathrm{CO}_{2}\right]$. PLoS ONE 8(12): e82712.

RIBEIRO VS ET AL. 2014. Chemical characterization and antioxidant properties of a new coffee blend with cocoa, coffee silver skin and green coffee minimally processed. Food Res Int 61: 39-47.
ROGERS S ET AL. 2008. Characteristics of milk powders produced by spray freeze drying. Dry Technol 26(4): 404412.

SALEEB FZ. 1975. Adsorption of carbon dioxide on roast and ground coffees. In: $7^{\text {th }}$ Asic Colloquium, Paris. $7^{\text {th }}$ International Scientific Colloquium on Coffee, Paris, p. 335-339.

SANTANA AA ET AL. 2014. Microencapsulation of pequi pulp by spray drying: use of modified starches as encapsulating agent. Eng Agríc 34(5): 980-991.

SARABANDI K, PEIGHAMBARDOUST SH AND SHIRMOHAMMADI M. 2014. Physical properties of spray dried grape syrup as affected by drying temperature and drying aids. Int J Agric Crop Sci 7: 928-934.

SCHENKER S ET AL. 2000. Pore structure of coffee beans affected by roasting conditions. J Food Sci 65(3): 452-457.

SHISHIR MRI ET AL. 2014. Physical properties of spraydried pink guava (Psidium Guajava) powder. Agric Sci Procedia 2: 74-81.

SHITTU TA AND LAWAL MO. 2007. Factors affecting instant properties of powdered cocoa beverages. Food Chem 100(1): 91-98.

SHRESTHA AK ET AL. 2007. Water sorption and glass transition properties of spray dried lactose hydrolysed skim milk powder. Food Sci Technol 40(9): 1593-1600.

SIEVETZ N AND DESROSIER NW. 1979. Coffee technology, Westport: Avi Publication Co. Available at: https://www. amazon.com/dp/0870552694/ref=olp_product_details?_e ncoding $=$ UTF8\&me $=$. Accessed on December 15, 2016.

TOTH J AND PALLAI-VARSANYI E. 2006. Drying of bovine serum albumin on inert particle surface in $\mathrm{msb}$ dryer. In: Proceedings of International Drying Symposium, Budapeste. International Drying Symposium, Budapeste, p. 1216-1222.

WANG N. 2012. Physicochemical changes of coffee beans during roasting. The University of Guelph, Canada.

WANG X AND LIM LT. 2014. Effect of roasting conditions on carbon dioxide degassing behavior in coffee. Food Res Int 61: 144-151.

WANG X AND LIM LT. 2015. Physicochemical characteristics of roasted coffee. In: Preedy VR (Ed), Coffee in health and disease prevention. San Diago: Elsevier Academic Press, USA, p. 247-254.

WILSON AJ. 1997. Preliminary investigations of oil biosynthesis in the coffee cherry. In: Proceedings of The $17^{\text {th }}$ Asic Colloquium, Paris. $17^{\text {th }}$ International Scientific Colloquium on Coffee, Paris, p. 92-99.

YAZDANI M ET AL. 2006. Moisture sorption isotherms and isosteric heat for pistachio. Eur Food Res Technol 223(5): 577-584. 